VAlentine, R. C. (1957). J. gen. Microbiol. 17, 474-479

\title{
The Action of Chemical Disinfectants on Bacteria in Droplets Compared with that in Large Volumes
}

\author{
By R. C. VALENTINE \\ National Institute for Medical Research, Mill Hill, \\ London, N.W. 7
}

SUMMARY : Because of adsorption phenomena, copper sulphate solutions containing traces of protein are less toxic to bacteria in droplets than to similar bacteria in large volumes. With dilute phenol solutions the reverse was found. The quantitative results suggest that the non-flagellate organism studied moves with about 25 times the energy of Brownian motion.

Although much information is available about the killing of bacteria by different chemicals, almost all of it has been obtained from investigations that used volumes of suspensions of the order of $1 \mathrm{ml}$. or more. Little has been published about the rate of killing of bacteria suspended in droplets owing, for the most part, to the difficulty of adapting the standard viability counting methods for use with such small samples. However, the urea method of measuring bacterial viability (Valentine \& Bradfield, 1954) does allow the $\%$ live organisms in small drops to be determined. In outline this method consists of incubating a drop of the suspension under investigation on the film of an electron microscope specimen support placed on a nutrient agar medium containing $3 \%(\mathrm{w} / \mathrm{v})$ urea. The urea does not stop the growth of any live bacteria in the drop but it does inhibit their division and each develops into a long filamentous form. The dead bacteria remain unaltered in appearance. After about $3 \mathrm{hr}$. of incubation, the film is fixed in formalin vapour, washed and examined in the electron microscope. A determination of the ratio of long to normal-length organisms then gives a reliable estimate of the ratio of live to dead bacteria originally in the drop. In the experiments now described, this urea method has been used to measure the rate of killing of bacteria by dilute copper sulphate and phenol solutions in drops $0.6 \mathrm{~mm}$. in diameter. Observation of bacteria in drops of this size with the light microscope showed that when the surface tension of the suspending fluid was about that of water, the bacteria arriving at the surface of the drop were held there by surface forces and unable to return to the interior. Within a few minutes, many of the bacteria in a small drop have gathered and remain on the surface and it is here that much of the interaction between them and any chemicals in the drop takes place. Adsorption phenomena may cause the chemical composition of this surface layer to differ from that of the interior and thus it is quite possible that the death-rate of bacteria in droplets containing toxic substances may be entirely different from that in larger volumes of the same suspension. This point is in fact demonstrated by the following experiments. 


\section{METHODS}

Bacteria. A paracolon bacterium designated as D. $201 \mathrm{H}$ (Fry \& Greaves, 1951) kindly supplied by Dr R. M. Fry was used; it is deposited in the National Collection of Type Cultures (Colindale) as NCTC 9793. It was grown on nutrient agar slopes prepared from the Difco dried product. Suspensions were made by removing sufficient growth from $18 \mathrm{hr}$. cultures and rapidly suspending it in the solutions under investigation. These were made to contain about $10^{7}$ bacteria $/ \mathrm{ml}$. of which, in all cases, $90 \%$ or more were initially viable as measured by the urea method.

Formation of droplets. A drop of the suspension was taken up immediately in a platinum loop. It was held in the same tube just above the surface of the suspension from which it had been taken. The tube was closed and there was negligible evaporation of the drop in $30 \mathrm{~min}$. which was the longest time involved in these experiments. By bending the platinum wire so that the loop was in a horizontal plane when removed from the liquid, the drop so formed was nearly a perfect sphere and had a diameter of $0.6 \mathrm{~mm}$. After the desired length of time, the drop was transferred for a viability count on to the film of the specimen support. This had already been placed on the nutrient agar containing $3 \%(\mathrm{w} / \mathrm{v})$ urea in a Petri dish warmed to $37^{\circ}$. A second drop was taken at the same time from the bulk suspension and placed on a second film in the same dish. The two samples thus received identical treatment except that in one the bactericidal action took place in a droplet and in the other in a comparatively large volume. The amount of the decrease in the viability in each case will be referred to respectively as killing in the drop and in bulk suspension. It was found that with the weak solutions used the bactericidal action could be stopped immediately the drop was on the film by piercing a very small hole in this with a drawn-out fibre of glass so that the drop diffused into the agar.

Viability counts. Counts were made by the urea method in the manner previously described (Valentine \& Bradfield, 1954). The results given are the mean counts made on three similar drops in each case. The errors quoted are the standard errors of this mean calculated as previously described from the total number of bacteria observed. No significant differences were found in the counts made on similar drops.

\section{RESULTS}

\section{Disinfection with copper sulphate}

The effect of various concentrations of copper sulphate on the bacteria suspended in $5 \mathrm{ml}$. volumes was first investigated. As is usual with metallic salts, the toxicity of the copper sulphate was found to be greatly decreased when broth or other material containing soluble protein was also present in solution. Even the small amount of broth carried over with the bacteria from the culture slope had an appreciable protective action. Thus there was markedly greater killing with organisms washed free from this by being shaken 
in distilled water and then centrifuged down, as compared with the killing of unwashed organisms. The results obtained are shown in Table 1.

Table 1. Effect of various concentrations of copper sulphate on washed and unwashed organisms

$\begin{array}{ccc}\begin{array}{c}\text { Concentration of } \\ \text { CuSO }\end{array} \text { solution } & \begin{array}{c}\text { Unwashed } \\ \text { organisms }\end{array} & \begin{array}{c}\text { Washed } \\ \text { organisms }\end{array} \\ \begin{array}{c}\text { Or) } \\ 10^{-4}\end{array} & 100 & (\%) \\ 3 \times 10^{-5} & 88 & 100 \\ 10^{-5} & 60 & 100 \\ 10^{-6} & 0 & 95 \\ & & 0\end{array}$

To study the effect of droplet suspension on the rate of disinfection, $10^{-5} \mathrm{M}$ copper sulphate solution was used. Suspensions of washed and unwashed organisms were prepared as before and this time viability counts were made on drops ( $0 \cdot 6 \mathrm{~mm}$. diameter) as well as on the bulk suspensions. Table 2 shows the $\%$ organisms killed in $\mathbf{3 0}$ min. under the various conditions. These results leave little doubt that the bactericidal action of the copper ions was markedly less in the drops than in bulk suspensions with the unwashed organisms, i.e. when a certain amount of soluble protein was also present. Many other similar experiments have always confirmed this point. The difference is less marked with washed organisms and becomes negligible when this washing has been repeated a number of times.

Table 2. Effect of copper sulphate on organisms in droplets compared with the effect in larger volumes

$\begin{array}{lcc} & \overbrace{\begin{array}{c}\text { In bulk } \\ (\%)\end{array}}^{\begin{array}{c}\text { Organisms killed in } 30 \text { min. } \\ \text { in } 10^{-5} \mathrm{M}-\mathrm{CuSO}_{4} \text { solution }\end{array}} \begin{array}{c}\text { In drop } \\ (\%)\end{array} \\ \text { Washed organisms } & \mathbf{9 4} \pm \mathbf{1} & 80 \pm 2 \\ \text { Unwashed organisms } & 60 \pm \mathbf{2 \cdot 5} & 10 \pm 1 \cdot 5\end{array}$

The rate of killing of unwashed organisms in drops and in bulk suspensions was then studied by determining the viability of samples at various times up to $20 \mathrm{~min}$. Table 3 shows how the \% organisms killed by $3 \times 10^{-5} \mathrm{M}$-copper sulphate solution varied with time. After $10 \mathrm{~min}$., the rate of killing in the bulk suspension was at least twice as great as in the drops and increased still further after this.

In order to confirm that the difference between survival in bulk suspensions and in the drops was a true surface effect, the result of adding a surface active agent was investigated. It was found that "Teepol $X$ " even at high concentrations (1/10) had no toxic action on the bacteria. At the same time a 1/10,000 dilution decreased the surface tension of water from 72 to 40 dynes 
$\mathrm{cm} .^{-1}$ and at this lowered surface tension the bacteria were seen to move freely from the surface back into the interior of the drop instead of being held by the surface forces. As expected, it was found that there was then no significant difference between the killing in bulk suspensions and in the drops. Table 4 shows the $\%$ of unwashed organisms killed after $15 \mathrm{~min}$. in $3 \times 10^{-5} \mathrm{M}$ copper sulphate, with and without the addition of Teepol at 1/10,000 dilution.

Table 3. Rate of killing of unwashed organisms by copper sulphate

\begin{tabular}{|c|c|c|}
\hline \multirow[b]{2}{*}{$\begin{array}{l}\text { Time } \\
\text { (min.) }\end{array}$} & \multicolumn{2}{|c|}{$\begin{array}{l}\text { Organisms killed in } \\
3 \times 10^{-5} \mathrm{M}^{-} \mathrm{CuSO}_{4}\end{array}$} \\
\hline & $\begin{array}{c}\text { In bulk } \\
(\%)\end{array}$ & $\begin{array}{c}\text { In drop } \\
(\%)\end{array}$ \\
\hline 1 & $3 \pm 2$ & - \\
\hline 3 & $5 \pm 2$ & $1 \pm 1$ \\
\hline 5 & $4 \pm 1 \frac{1}{2}$ & 二- \\
\hline 6 & $10 \pm 2$ & $2 \frac{1}{2} \pm 1$ \\
\hline 7 & $10 \pm 2$ & $4 \pm 3$ \\
\hline 10 & $18+3$ & $4+1 \frac{1}{8}$ \\
\hline 15 & $38 \pm 2 \frac{1}{2}$ & $z^{-2}$ \\
\hline 16 & $37 \pm 2 \frac{1}{2}$ & $9 \pm 2$ \\
\hline 20 & $56 \pm 2$ & $11 \pm 3$ \\
\hline
\end{tabular}

Table 4. Effect of adding Teepol to the copper sulphate solution

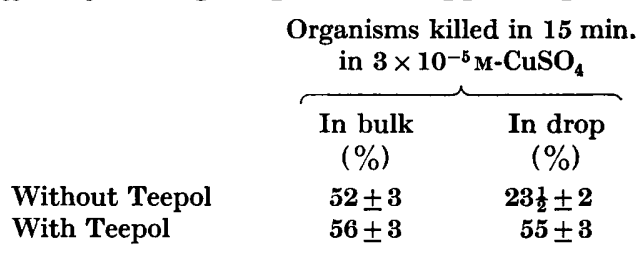

\section{Disinfection with phenol}

Phenol was equally toxic to washed or unwashed organisms. The effect of various concentrations of phenol on the organisms in bulk suspensions and in drops was studied in the same way as the copper sulphate. The results are shown in Table 5. It is clear that in the two more dilute concentrations used $(0.1$ and $0.2 \%, w / v$, phenol) there was markedly more killing in the drops, but with $0.3 \%(\mathrm{w} / \mathrm{v})$ or stronger phenol this effect was no longer observed. A particularly interesting observation here was that there was actually more

Table 5. Effect of phenol on organisms in droplets compared with the effect in larger volumes

$\begin{array}{ccc}\begin{array}{c}\text { Concentration } \\ \text { of phenol }\end{array} & \overbrace{\text { In bulk }}^{\text {Organisms killed in } 23 \text { min. }} \\ (\%) & (\%) & \begin{array}{c}\text { In drop } \\ (\%)\end{array} \\ 0 \cdot 1 & 2 \pm 2 & 40 \pm 2 \\ 0 \cdot 2 & 4 \pm 2 & 25 \pm 3 \\ 0 \cdot 3 & 25 \pm 3 & 28 \pm 3 \\ 0 \cdot 6 & 96 \pm 2 & 95 \pm 2\end{array}$


killing in the drops with $0 \cdot 1 \%(\mathrm{w} / \mathrm{v})$ phenol than there was with $0 \cdot 2 \%(\mathrm{w} / \mathrm{v})$ phenol. The killing after various times in $0.1 \%(\mathrm{w} / \mathrm{v})$ phenol is shown in Table 6.

\begin{tabular}{|c|c|c|}
\hline \multirow[b]{2}{*}{$\begin{array}{l}\text { Time } \\
\text { (min.) }\end{array}$} & \multicolumn{2}{|c|}{$\begin{array}{l}\text { Organisms killed in } \\
0 \cdot 1 \%(\mathrm{w} / \mathrm{v}) \text { phenol }\end{array}$} \\
\hline & $\begin{array}{c}\text { In bulk } \\
(\%)\end{array}$ & $\begin{array}{c}\text { In drop } \\
(\%)\end{array}$ \\
\hline o & 0 & 0 \\
\hline 5 & 0 & $10 \pm 3$ \\
\hline 10 & 0 & $40 \pm 5$ \\
\hline 15 & 0 & $40 \pm 3$ \\
\hline
\end{tabular}

\section{DISCUSSION}

Any dissolved substance that lowers the surface tension of the drop will be adsorbed so that its concentration in the surface layer is greater than in the rest of the drop (Gibbs's adsorption law; see Bull, 1951). In the case of the experiments with copper sulphate solutions, small amounts of protein were present and these would have concentrated in the surface. As it was found that this protein decreased the toxicity of copper ions, the surface layer of the drop was then less poisonous than the interior. This was confirmed by finding that there was markedly less killing of bacteria in droplets compared with otherwise identical bulk suspensions. The rate of killing was at least twice as great in bulk suspensions as in the drops after about $10 \mathrm{~min}$. If there had been no killing of the bacteria on the surface, then it appears that half the bacteria in the drop must have been on the surface by that time; if there was some killing on the surface, then there must have been rather more than this. It is clear that where the action of a disinfectant is decreased by the presence of protein, droplet suspensions of bacteria may survive concentrations of this disinfectant which are lethal to them when in bulk suspensions.

With phenol, on the other hand, which itself lowers surface tension and is thus concentrated on the surface, the opposite result was found. A concentration of $0.1 \%(\mathrm{w} / \mathrm{v})$ phenol that was almost without bactericidal action when tested on bulk suspensions proved to kill nearly half the bacteria in $10 \mathrm{~min}$. when in a droplet. Presumably the increased concentration of phenol in the surface layer was sufficient to kill the bacteria that reached and were held there. That a stronger concentration $(0.2 \%, \mathrm{w} / \mathrm{v})$ should kill fewer bacteria in the droplets than the $0.1 \%$ concentration seems a paradox, but can be explained as follows. If, as will be suggested later, much of the motion of the organisms is due to their own active movements, then it may well be that the $0 \cdot 2 \%(\mathrm{w} / \mathrm{v})$ phenol, though only beginning to show a slight bactericidal action in bulk, might nevertheless have markedly decreased the speed of motion of the bacteria. Thus when it acted on the organisms in the interior of the drop it may actually have served to prevent them rushing to their death in the more toxic surface layer. With the more dilute phenol solution, the bacteria within the 
drop, because they were moving faster, may have reached and been killed on the still poisonous surface in larger numbers.

If the movement of the bacteria were due entirely to Brownian motion, then the time required for half the population in a drop $0.6 \mathrm{~mm}$. in diameter to reach and be held in the surface can be calculated. The diffusion equation for this case of a spherical drop was solved for the appropriate boundary conditions and showed that the number of bacteria on the surface would rise to half the number originally in the drop in $\mathbf{2 7 0} \mathrm{min}$. (The organisms were almost spherical; for the purposes of this calculation they were assumed to be spheres of diameter $1 \mu$. and of density $1.1 \mathrm{~g} . \mathrm{cm}^{-3}$.) Observations on inanimate objects (polystyrene latex spheres of diameter $0.25 \mu$.) have shown that their motion under similar conditions conforms exactly to that calculated for bodies in Brownian motion. Now both the copper sulphate and the phenol experiments suggest that in fact about half the bacteria must have reached the surface within $10 \mathrm{~min}$. Their mean energy of motion, which if random is proportional to the time taken for a given fraction of the bacteria to reach the surface thus appears to have been some 25 or more times that of Brownian motion. These bacteria are smooth almost spherical organisms and lack all traces of flagella; nevertheless, it seems that they can move themselves in a given time about 5 (i.e. $\sqrt{ } 25$ ) times as far as a similar inanimate object would be moved by Brownian motion.

Much of this work was carried out at the Cavendish Laboratory, Cambridge, with the aid of a grant from the Agricultural Research Council. Throughout I have been indebted to Dr J. R. G. Bradfield for much help and encouragement.

\section{REFERENCES}

Bull, H. B. (1951). Physical Biochemistry, 2nd ed. p. 198. New York: John Wiley and Sons.

Fry, R. M. \& Greaves, R. I. N. (1951). The survival of bacteria during and after drying. J. Hyg., Camb., 49, 220.

Valentine, R. C. \& Bradfield, J. R. G. (1954). The urea method for bacterial viability counts with the electron microscope and its relation to other viability counting methods. J. gen. Microbiol. 11, 349.

(Received 11 April 1957) 